水 文 $\cdot$ 水 資 源 学 会 誌

J. Japan Soc. Hydrol.\& W ater Resour.

\begin{tabular}{ll} 
Vol. 18, No. 3 (2005) $\quad$ pp. 293-305 \\
\hline
\end{tabular}

\title{
Distributed Runoff Model Linking Surface with Groundwater Processes
}

\author{
地下水と地表水流出過程を結合した分布型流出モデルに関する研究
}

\author{
A min NAWAHDA ${ }^{1)}$ T oshiharu KOJIRI ${ }^{2)}$ Ichirow KAIHOT U ${ }^{3)}$ \\ アミンナワダ 小尻利治開發一郎
}

1) Graduate School of Engineering, Kyoto University 京都大学大学院工学研究科

2) Disaster Prevention Research Institute, Kyoto University 京都大学防災研究所

3) Faculty of Integrated Arts and Sciences, Hiroshima University 広島大学総合科学部

\begin{abstract}
A method with multi-layer and grid-based runoff model using Hydro-BEAM (Hydrological River Basin Environment A ssessment $\mathrm{Model}$ ) is proposed to analyze the integrated hy drological processes. The spatiotemporal $\mathrm{w}$ ater flow is calculated with the kinematic wave model for surface runoff, Richards' equation for unsaturated subsurface flow and the unconfined flow model for groundwater. The initial loss of rainfall due to interception by depression storage process is considered here. Moreover the basin division and land use dynamics are introduced to analyze reservoir operation and land utilization with human activities. The proposed model is calibrated for different initial conditions and parameters, and applied to the $\mathrm{Y}$ asu River to verify the dynamic linkage between surface and groundw ater.

Key words : Distributed runoff model, Parameterization, Saturated and unsaturated flow, Spatiotemporal distribution.

本研究は, 多層メッシュ型流出モデルであるHydro-BEA M (Hydrological River Basin Environment A ssessment Model)におい て, 表面流・飽和中間流には Kinematic wave model を，不飽和中間流には Richards' equation，地下水には不圧地下水流を適用し， 产の総合化を図ったものである . 流出モデルに関しては, 流出, 土猿水分量 , 地下水涵養量の動態をモデル化すると共に, 表面貯 留での初期損失を考慮した . また, ダム貯水池操作を組み込むための流域分割と, 人間活動を考慮すべく土地利用の時間変化を用 いた .モデルは初期条件やパラメータを最適化して, 琵琶湖野洲川流域に適用し, 地表水と地下水の間の動的関係を検証した . キーワード : 分布型流出モデル, パラメータ化, 飽和・不飽和中間流 , 時空間分布
\end{abstract}

\section{INTRODUCTION}

The hydrological cycle involves complicated interactions between atmosphere layer, surface and ground layers. A large-scale model was developed for areas with a shallow groundwater table, and it was found that $5 \sim 20 \%$ of the groundwater evaporates from the water shed each year (Jennifer et al., 2002). The integrated hydrological modeling is achieved by dynamic linking and simultaneous calculation of the water cycle related processes. There will be almost no surface runoff unless the surface soil is saturated, or a relatively impermeable surface exists there. T he saturation condition depends on the groundw ater level, ev aporation, wa ter uptake by plants, infiltration, irrigation, and other existing sinks or sources. Precipitation infiltrates in grids and the excess forms the runoff. $T$ he runoff flows later ally to a seasonal stream during rain events through the surface and subsurface layers (Johansson P., 1986) .

$T$ raditionally the lumped models simulate the formation of the surface runoff. Most of these models are based on the assumptions of uniformity and

1) Y oshida-Honmachi, Saky o-ku, Ky oto 606-8501 土木システム専攻 $\bar{T} 606-8501$ 京都市左京区吉田本町

2) Uji, Ky oto 611-0011 水資源研究センター T611-0011 宇治市五ヶ庄

3) Higashihir oshima, Hiroshima 739-8521 T739-8521 東広島市鏡山1-7-1 
linearity in watersheds. In reality these assumptions include a high percentage of errors. The distributed rainfall-runoff (Hydro-BEA M) was introduced in order to overcome the shortcomings of these lumped models (Kojiri T ., 2000). In HydroBEA M, the water shed is divided into two types of grids; terrain grids that have only excess precipitation as input, and river grids having both excess precipitation and river flow as input. The surface runoff in each grid is transformed into the corresponding next terrain or river grid. Each grid includes five land use types; mountain, paddy, agriculture, urban, and water body. At each grid the heat balance method is used to calculate the evaporation and snow melt, and then the kinematic wave model is used for calculating the surface runoff. T he linear storage model is used for groundwater flow modeling. The ground subsurface of the whole basin is divided into four uniform layers. $T$ he mass balance and the momentum equations are formulated as follows;

$$
\begin{aligned}
& \frac{\partial A}{\partial t}+\frac{\partial Q}{\partial x}=q(t, x) \\
& A=f(x, Q)=\mathbf{\alpha} Q^{\beta}
\end{aligned}
$$

where $A$ is the discharge area, $Q$ is the flow rate, $q$ is the spatiotemporal effective rainfall, and $\alpha$ and $\beta$ are parameters. T he general momentum equation from the first to forth layer is formulated according to Darcy 's law.

In this study the watershed is treated more extensively with specific details. These details include distributed criteria for each grid such as; geological cross sections, soil maps, dynamics of land uses, sinks and sources, and other hydroclimatic processes. The flow chart of the calculation procedure for the integrated Hydro-BEAM is show $n$ in Fig. 1.

\section{FORMULATION OF INTEGRATED HY- DROLOGICAL MODELING}

\section{Spatiotemporal variability of hydrological pa-} rameter

The surface and subsurface hy drological parameters vary in space and/or time; this variability causes a significant change in the shape of the

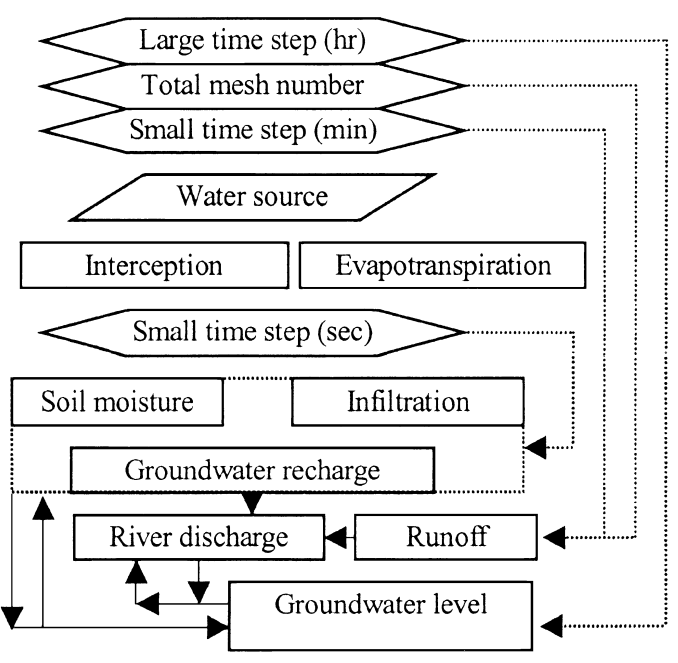

Fig. 1 The main flow chart of integrated HydroBEA M.

river hy drograph. T he variability can be caused by the basin characteristics, precipitation, and human utilization of land. Therefore the watershed is divided into catchments, each catchement is divided into square grids, and each grid is connected to a drainage network represented by a channel segment. The variability of the hydrological parameters for each grid is integrated, and then the grid is divided into elements of uniform parameters. The number of elements is decided by the surface properties and availability of hydrological data.

In the kinematic wave model the soil roughness affects both the speed of runoff and the infiltration rate, infiltration affects both the depth of the surface runoff and the groundwater recharge. Therefore for each type of soil and land use there is preliminary set of roughness and infiltration coefficients. These coefficients are evaluated by using scaling methods, the scaling factors are derived by two steps; first is soil sampling from different locations in the watershed and second is to use the probability densities and auto correlation structures for the calibration. The rational method for calculating the representative infiltration and roughness coefficients for each grid is show $n$ in Fig. 2.

It show s the soil map based parameterization $n_{j}{ }^{*}$, 


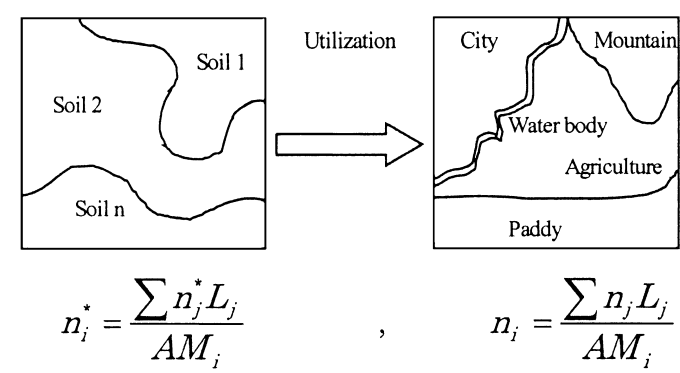

Fig. 2 Integrated hydrological parameterizations based on distributed soils and land uses.

and the land use based parameterization $n_{j}$, where $\mathrm{n}$ is a surface hydrological parameter, $L_{j}$ is the area percentage of the sub- parameter $n_{j}, j$ is the number of the considered land uses or soils, and $A M_{i}$ is the area of the $i^{\text {th }}$ grid. A $n$ example is illustrated by the above figure. A $n$ infiltration coefficient for a grid with sandy soil (normalized $n * \approx 1.0$ ) and citytyped land use $(n \approx 0.0)$ has a value that is not large as if the parameterization is only based on soil map, and is not small as if it is only based on land use map. In other words the two values $\mathrm{n}$ and $n *$ represent the limits of the variability domain; therefore the value of infiltration coefficient is selected from this domain. In Hydro-BEA M the harmonic mean value is selected.

\section{Runoff process}

The grids of the basin are classified into river and slope types, and then the kinematic wave model for unsteady one-dimensional flow is used, $\alpha$ and $\beta$ in Eq. (2) are computed by using Manning equation:

$$
Q=\frac{\sqrt{\sin (\varphi)}}{n_{r}} A H^{\frac{2}{3}}
$$

where $\varphi$ is the grid average slope, $n_{r}$ is the roughness coefficient, and $H$ is the hydraulic radius. T he finite difference method is used to approximate Eq.

(1) as shown in Eq. (4), its numerical solution is achieved by using the Iterative Newton Method (Chow V., 1988) as follows;

$$
\frac{Q_{i+1}^{j+1}-Q_{i}^{j+1}}{\Delta x}+\frac{A_{i+1}^{j+1}-A_{i+1}^{j}}{\Delta t}=\frac{q_{i+1}^{j+1}-q_{i+1}^{j}}{2}
$$

where: $A_{i+1}^{j+1}=\mathbf{\alpha}\left(Q_{i+1}^{j+1}\right)^{\beta}, A_{i+1}^{j}=\mathbf{\alpha}\left(Q_{i+1}^{j}\right)^{\beta}$

\section{Subsurface flow process}

Richards' equation Eq. (5) for unsaturated flow in one dimension (Richards L. A ., 1931) is used to simulate the distribution of the soil moisture and to estimate the spatiotemporal groundw ater recharge.

$$
C \frac{\partial \Psi}{\partial t}=\frac{\partial}{\partial z}\left[K(\Psi)\left(\frac{\partial \Psi}{\partial z}+1\right)\right]
$$

where, $C$ is the specific water capacity, $\psi$ is the water potential head, $K$ is the hydraulic conductivity, $z$ is the vertical coordinate and $t$ is time. The numerical solution for Eq. (5) is achieved by using the finite difference implicit scheme as given by Eq. (6), the boundary conditions can be handled by using Eq. (7) and Eq. (8) (Baker L., 1995b) as follow s;

$$
\begin{aligned}
C_{i} & \frac{\Psi_{i}^{t+1}-\Psi_{i}^{t+1}}{\Delta t} \\
= & \frac{1}{\Delta z}\left(K_{i p} \frac{\Psi_{i+1}^{t+1}-\Psi_{i}^{t+1}}{\Delta z}+K_{i p}\right) \\
& -\frac{1}{\Delta z}\left(K_{i m} \frac{\Psi_{i}^{t+1}-\Psi_{i+1}^{t+1}}{\Delta z}+K_{i m}\right)
\end{aligned}
$$

Bottom node:

$$
\begin{gathered}
\left(C_{i}+\frac{\Delta t}{\Delta z^{2}}\left(K_{i m}+K_{i p}\right)\right) \Psi_{i}^{t+1}-\frac{\Delta t}{\Delta z^{2}} K_{i p} \Psi_{i+1}^{t+1}= \\
C_{i} \Psi_{i}^{t}+\frac{\Delta t}{\Delta z}\left(K_{i p}-K_{i m}\right)+\frac{\Delta t}{\Delta z^{2}} K_{i m} \Psi_{0}
\end{gathered}
$$

Surface node:

$$
\begin{gathered}
\frac{\Delta t}{\Delta z^{2}} K_{i m} \Psi_{n p-2}^{t+1}+\left(C_{n p-1}+\frac{\Delta t}{\Delta z^{2}} K_{i m}\right) \Psi_{n p-1}^{t+1}= \\
C_{n p-1} \Psi_{n p-1}^{t} \frac{\Delta t}{\Delta z}\left(K_{i m}+q_{i n f}-P\right)
\end{gathered}
$$

where $\Psi_{0}$ is the initial constant potential head at the bottom of the unsaturated layer, $q_{\text {inf }}$ is the infiltration flow rate including evapotranspiration, $P$ is the uptake by plants, $K_{i p}$ is the upward arithmetic mean of the hydraulic conductivities and $K_{i m}$ is the downward arithmetic mean of the hydraulic conductivities for two successive nodes in the vertical direction. The potential pressure-saturation relation is simulated using van-Genuchten style equations;

$$
S=\frac{\theta-\theta_{r}}{\theta_{s}-\theta_{r}}=\left[\frac{1}{1+\left(\Psi / \Psi_{d}\right)^{\alpha}}\right]^{/ a}
$$

$$
K=K_{s} S_{t}^{\urcorner}
$$


where $S_{t}$ is the effective saturation, $\theta_{r}$ is the residual water content, $\theta_{s}$ is the saturated water content, $\mathbf{\alpha}$ and $\lambda$ are the van-Genuchten fitting parameters, $\Psi_{d}$ is the displacement pressure head, $K_{s}$ is the saturated hydraulic conductivity and $\eta$ is the exponential soil parameter.

\section{Groundwater flow process}

Quasi-three dimensional differential equation for the transient unconfined groundwater flow with Dupuit assumptions is given by

$$
\frac{1}{2}\left(K_{x} \frac{\partial^{2} h^{2}}{\partial x^{2}}+K_{y} \frac{\partial^{2} h^{2}}{\partial y^{2}}\right)=S \frac{\partial h}{\partial t}-R(x, y, t)
$$

where $h$ is the groundwater level, $K$ is the hydraulic conductivity, $S$ is the specific yield, $R$ is the distributed groundwater recharge, $x$ and $y$ are the displacement coordinates, and $t$ is time. Iterative implicit Crank-Nicolson equation form is used to approximate the solution of the quasi-three dimensional partial differential equation for groundwater flow (W ang H. and A nderson M., 1982) as follow s;

$$
\begin{aligned}
& v_{i j}^{n+1}=\frac{1}{\left(\frac{a^{2} S}{4 K \sqrt{v_{i j}^{n} \Delta t}}+\mathbf{\alpha}\right)}\left(\mathbf{a} v m_{i j}^{n+1}\right. \\
& +\frac{a^{2} S}{4 K \sqrt{v_{i j}^{n} \Delta t}} v_{i j}^{n} \\
& \left.+(1-\mathbf{\alpha})\left(v m_{i j}^{n}-v_{i j}^{n}\right)+\frac{a^{2} R_{i j}^{n}}{2 K}\right)
\end{aligned}
$$

where $v=h^{2}, a=\Delta x^{2}=\Delta y^{2}, i$ and $j$ are displacement coordinates, $n$ is time step index, $\mathbf{\alpha}=0.5$, and $v m$ is the arithmetic mean of the surrounding star heads, the available values for the hydraulic conductivity are only in the vertical direction, for alluvial deposits the ratio of horizontal and the vertical values varies from 2 to 20 (Bouwer H., 1978). T he boundary conditions for the groundwater model are (a) known head, (b) known flow, and (c) known flow and head. The three types of boundary conditions have an interaction between the sub-models of the integrated Hydro-BEAM. The simulated groundwater level will be used in the unsaturated flow model, which is running with a small time step compared with the time step of the groundwater model, therefore the groundwater flow is assumed to be steady, and the distributed groundwater re- charge is accumulated at every small time step.

\section{Interception process}

A fraction of rainfall is not contributing to the runoff formation due to interception. The interception occurs at the roof of houses in city grids, also occurs over the vegetation cov-er which has a certain storage capacity. A fraction of the intercepted water evaporates, another fraction falls to the ground in large drops or flows over the body of the interceptor to reach the ground surface. T he interception process is highly affected by the rainfall intensity and the conditions of the interceptor. Similar to the interception by vegetation that was derived by Horton (1919), the interception caused by residential buildings can be treated as follows:

$$
I=D+V E t
$$

where $I$ is the interception loss, $D$ is the inter- ception storage depth, $V$ is the ratio of build- ing 's surface area to its projected area on the ground, $E$ is the evaporation rate, and $t$ is the storm duration. The interception by plants is formulated in order to include the seasonality, also the fluctuation of the leaf area indices is included in the estimation of both interception and evaporation amounts according to rainfall intensity.

\section{Evapotranspiration process (ET)}

Evapotranspiration is a description for both evaporation of liquid or solid water plus transpiration from plants, the temporal behaviors of weather conditions and the groundwater level affect the rate of ET. T here are many methods to estimate ET according to the amount of available meteorological data. The heat and mass balance methods are used to evaluate ET for each grid in the watershed as a function of the net solar radiation (Kojiri T ., 2000) as follows;

$\begin{array}{ll}\text { Heat balance: } & I R=\sigma T^{4}+H S+l E+Q_{q} \\ \text { Input radiation: } & I R=(1-r e f) S R+L R \\ \text { Sensible heat: } & H S=C_{p} \rho C_{H} U\left(T_{s}-T\right) \\ \text { Latent heat: } & I E=\ell \rho C_{E} U\left(q_{s}-q_{h}\right)\end{array}$ where $I R$ is the input radiation, $\sigma$ is the StefanBoltzmann constant, $T$ is the atmosphere temperature, $H S$ is the sensible heat flux, $l E$ is the latent 
heat flux, $Q_{q}$ is the storage heat, ref is the albedo, $S R$ is the incoming solar radiation flux, $L R$ is the long wave radiation, $C_{p}$ is the specific heat at constant pressure, $\rho$ is the atmosphere density, $C_{H}$ is bulk coefficient of sensible heat, $U$ is the wind velocity, $T_{s}$ is the atmosphere temperature near surface grounds, $q_{s}$ is the specific humidity at water surface temperature, $q_{h}$ is the specific humidity of air, $\ell$ is the latent heat of vaporization, and $C_{E}$ is the bulk coefficient of latent heat. ET is highly variable because it is affected by type of plant, growing stage, available soil moistures, and weather conditions.

\section{Snowfall and snowmelt processes}

The snow fall and snow melt processes are simulated by using the energy balance at the earth's surface. A single layer of snow is assumed, then snowmelt, refreezing and cooling are formulated. A $n$ empirical formula for the threshold temperature T $\mathrm{c}$ is evaluated for each grid in order to predict the formation of snow and rain (Park et al., 2003).

$$
T_{c}=11.01-1.5 e_{a}
$$

where $e_{a}$ is the vapor pressure. If $T>T_{c}$; then rainfall, if $T \leq T_{c}$; then snow fall. T he snow melt is simulated with an updated energy balance equation that includes the snow melt heat $Q_{m}$, temperature near the snow surface $T_{S N}$, snow cover stored heat $Q_{s}$, rainfall heat $Q_{r}$, and the latent heat for the snow layer is given by

$$
Q m=I R-\sigma T_{s}^{4}+H S+L E+Q_{s}+Q_{r}
$$

The snowmelt related processes are eva- luated according to the following conditions;

1) T emperature rise: $Q_{m} \geq 0$ and $T_{S N}<0$

2) Snow melt: $\quad Q_{m} \geq 0$ and $T_{S N}=0$

3) Refreezing: $\quad Q_{m}<0$ and $T_{S N}=0$

4) Cooling: $\quad Q_{m}<0$ and $T_{S N}<0$

8. Reservoir operation and change of basin situation

\section{1) Basin division}

The basin division approach can be defined as dividing the watershed that has a reservoir into upper and lower parts. Compared with the lower catchments, the upper catchments of the watershed are subjected to precipitation that differs in time and amount, also the stratigraphy of the low er part differs from the upper part. T he analytical solution for the conservation of mass and momentum Eqs. (1) and (2) show that the speed of the kinematic wave is affected by the runoff depth. Therefore the wave propagation from the upper catchments to the lower catchments will be subjected to the kinematic wave shock (Shin H., 1979). On the other hand the reservoir operation can be considered as a strong dow $n$ stream control for the developed kinematic wave from the upper catchments, therefore the kinematic wave approximation will be no longer valid if the reservoir operation is not included (I shihara T ., 1959). A Iso the probabilistic nature of the reservoir operation hardens the process of integrating with the physical hy drological models, due to different simulation and operation times. T herefore the seasonality of the reservoir operation, and the extremes of the seasonal water demands and safety operation are set in the hydrological model, and then linear storage model is used for routing the water in the reservoir. Two approaches are introduced in this study for estimating the release of the reservoir:

a) Formulated operation rules: For immediate supply from the reservoir, and according to this approach the reservoir is oper ated according to certain specified rules which can be represented in a polynomial form with respect to an objective release as follow s;

$$
\begin{array}{r}
\text { Release }=\text { Qhase }+ \text { Qdom }+ \text { Qele } \\
+ \text { Qind }+ \text { Qirr }+Q M
\end{array}
$$

where Qbase is the river base flow, Qdom is the domestic water supply, Qele is the hydropow er water supply, Qind is the industry water supply, Qirr is the irrigation water supply, and $Q M$ is the monitoring flow rate. The polynomial should have a positive coefficient especially for the last term, and must start from the origin.

b) Iterative operating: For separated supply from the reservoir, this approach is intro- duced for reservoirs which have detailed operation rules that involve maintaining a minimum base flow in 
downstream river grids or supplying fluctuation human related needs or maintaining a specific temporal storage. At first Hydro-BEAM is initialized with an actual storage and release amounts. $T$ hen the seasonal user-defined main operation constrains such as maximum and minimum storage and/or allowed water levels are formulated into the iter ative method, because the calculating order in Hydro-BEA $M$ is achieved form the upstream to the downstream simultaneously, ther efore a reservoir in the upper catchments will be operated before the runoff contribution in the lower catchments is calculated. T herefore an initial guess of release is assumed then Hydro-BEA M simulates the runoff down to the monitoring point then the river discharge is compared with the desired discharge $Q M$ as illustrated in Fig. 3., this procedure is repeated until certain difference or a maximum number of iterations are achieved. The iterations

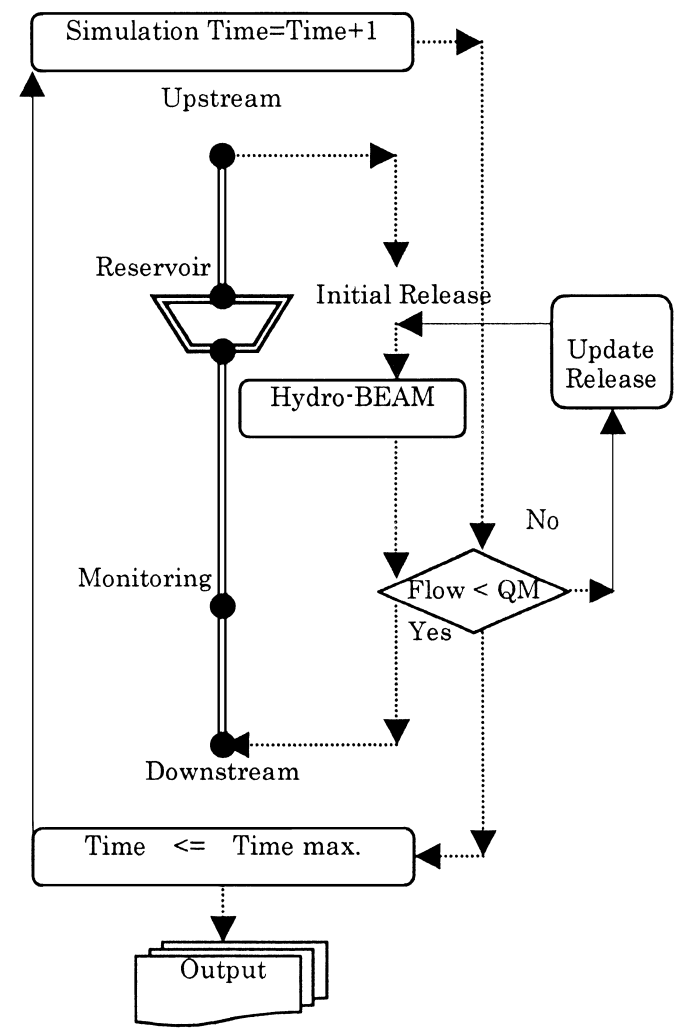

Fig. 3 Illustration of the iterative method for reservoir flow routing. are performed according to the user-defined operation time in order to save computing time. T he output of the iteration method is used to simulate the fluctuation of the storage, in order to calculate the storage the calculated releases and the HydroBEAM simulated inflow at the reservoir are routed linearly. There will be a deficit between the observed and simulated storages, this deficit can be used to estimate the hidden losses of the reservoir.

\section{2 ) Dynamics of land use}

$T$ he changes of land uses within the w ater- shed will occur dynamically in space and/or in time. Therefore modeling the hydroclimatic processes in the watershed such as stream flows, evapotranspiration, and soil moisture, Hydro-BEAM allows for an automatic adjust-ment of the distribution of land uses for each grid. On the other hand the hydrological parameters are also subjected to the same dynamic behavior. Therefore a seasonal parameterization for surface roughness, infiltration, and irrigation amounts is prepared to simulate the dynamics of land uses. This behavior of land is related to the residence time of water in the watershed and to the human utilization of land. T he land use dy namics approach can be applied for deterministic schemes or stochastic schemes by considering several scenarios of hypothetical changes in land uses.

\section{CASE STUDY: THE YASU RIVER BASIN}

The $\mathrm{Y}$ asu River is located in Shiga prefecture, Japan, and is one of the main water sources for Lake Biwa. Averaged annual precipitation for the regions ranges from 1550-2050 mm for the lower and upper catchments, respectively. The area of the whole basin is $445 \mathrm{~km}^{2}$ (see Fig. 4). T he length of the river channel is $95 \mathrm{~km}$. Small river flows and draw down of the groundwater level in the lower catchments and conservation of the water quality are the main concerns in the $\mathrm{Y}$ asu River basin.

Many studies have been carried out for developing a hydrological model for the $\mathrm{Y}$ asu River basin. $T$ he tank model was used for simulating the runoff 


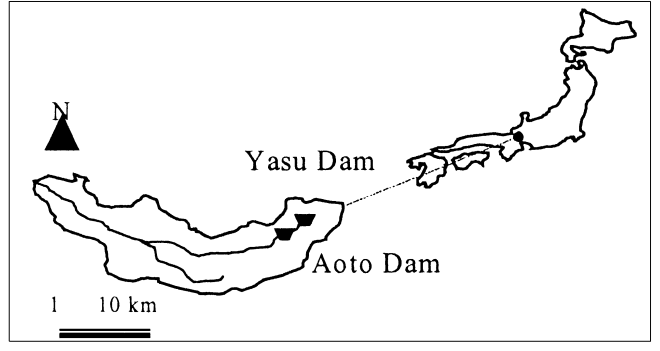

Fig. 4 The Y asu River basin / Japan.

and the operation of reservoirs for the upper catchments (Kato T ., 2002) .

In the low er catchments of the basin a groundw ater model was developed to investigate the impacts of land use changes (Kimaro T., 2002) and the simulation results show a draw down of the groundwater levels. T hough the mentioned studies were limited to sub-catchments in the $Y$ asu River basin, the researchers thought that there might be a strong relation between the exploding urbanization and the change in land uses, and the change of both groundwater levels and shape of the hydrographs of the $\mathrm{Y}$ asu River.

The distributed spatiotemporal hydrological data for the $Y$ asu River basin were collected at necessary monitoring stations. Spatial data includes geological formation, soil map, elevation, land uses, slope, flow direction, and existing sewers. T emporal data includes meteorological data, land utilization, groundwater level, operation of distributed sinks, water consumption, and seasonal measurements of the hydrological parameters.

$\mathrm{T}$ he basin is divided into one kilometer by one kilometer square grids. Then land uses are classified into five ty pes as follow s; 1) mountains and forests 2) paddy fields 3) farms 4) urban areas 5) $w$ ater bodies. T here are two reservoirs the $Y$ asu and the A oto reservoirs. T he reservoirs are used to supply domestic water $\left(0.080 \mathrm{~m}^{3} / \mathrm{sec}\right)$ and to satisfy industrial water demand $\left(0.533 \mathrm{~m}^{3} / \mathrm{sec}\right)$.

During the past 30 years (1970-2000), detailed measurements of meteorological data, groundwater levels, and runoff were measured along the $\mathrm{Y}$ asu River. Most of the simulated hydroclimatic processes require specific geological data and soil data like soil type, porosity and hydraulic conductivity. Despite the need of soil and geological data, fine resolution data is not available in digital form.

$T$ he soil characteristics and geological data are extracted from the already available hardcopy soil maps. The geological structures are used to determine the boundaries of the groundwater model. The data used for the geological analysis also extracted from drillers' logs. This information was used to prepare geological cross sections in $\mathrm{Y}$ asu River basin. There are four main types of rocks such as granite, chert, sandstone, and limestone. $T$ he soil and the geological maps are used in order to distribute the soil types and geological formations for each grid. T here are five main soil types; gray low land, gray, peat, not matured soil, and dry brown forest soils. Table 1 lists some of the field sampling analy sis.

A ccording to the drillers' logs and geological cross sections of the study area, there are mainly unconfined and confined layers respectively. The number of boring wells is so large, they are available at every $100 \mathrm{~m}$ between section $A$ and section $B$ (see Fig. 5.). The unconfined layer is not the

T able 1 Distributed physical soil parameters at $\mathrm{Y}$ asu River basin.

\begin{tabular}{|l|c|c|c|}
\hline Location & $\begin{array}{c}\Theta \\
(\%)\end{array}$ & Porosity $(\%)$ & $\mathrm{K}(\mathrm{cm} / \mathrm{sec})$ \\
\hline Farms & 36 & 49.9 & 0.0322 \\
Mountain & 27.7 & 68.3 & 0.607 \\
Paddy & 48.9 & 49 & 0.00034 \\
\hline
\end{tabular}

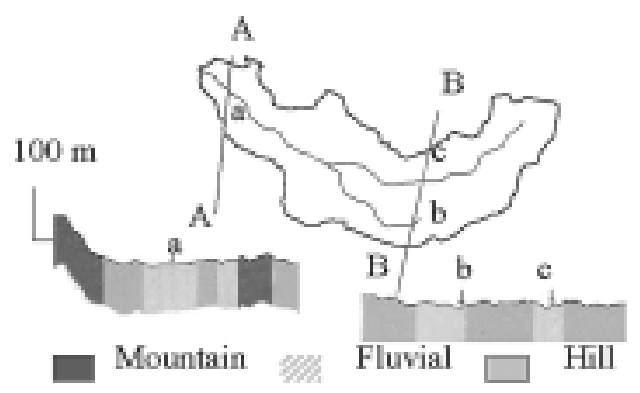

Fig. 5 Geological sections at the Y asu River basin. 
same in all grids (see Fig. 6.), ther efore a constant average thickness is assumed all over the basin, and the unconfined layer has an average thickness of $11 \mathrm{~m}$. The hydraulic parameters of the unconfined layer are determined by the rational method for the surface sub-layers (see Fig. 7.). T he ranges for hydraulic conductivities for each sub-layer are listed in Table 2.

The groundwater divide in south, north, and east of the $\mathrm{Y}$ asu Basin forms the basin boundaries. These boundaries are assumed to be no-flow boundaries. The western boundary will be used for calibrating the groundwater model. The recharge sources are mainly the rainfall and irrigation. The

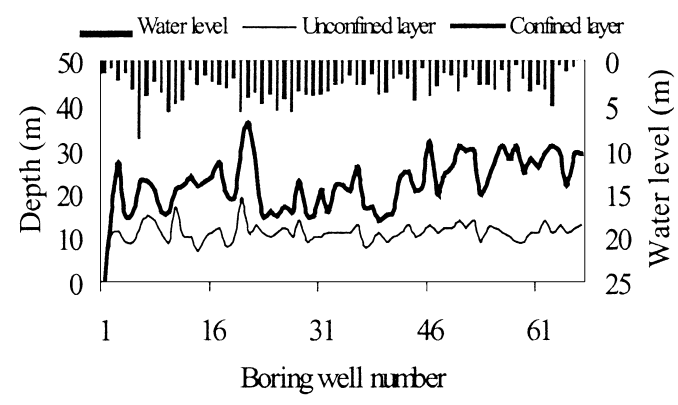

Fig. 6 Distributed representative boring wells.

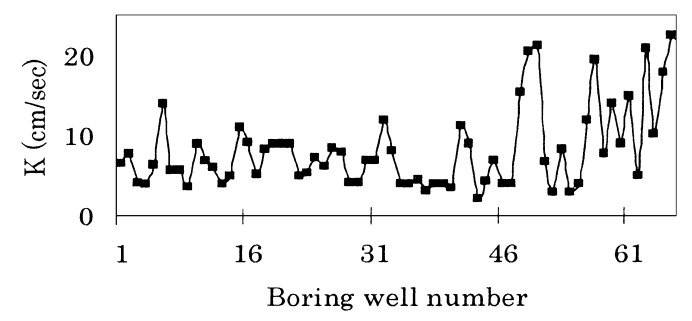

Fig. 7 Distributed hy draulic conductivities.

Table 2 Distributed stratigraphy in the lower Y asu River basin.

\begin{tabular}{|c|c|c|}
\hline $\begin{array}{c}\text { Layer } \\
\text { name }\end{array}$ & Height $(\mathrm{m})$ & $\mathrm{K}(\mathrm{cm} / \mathrm{sec})$ \\
\hline $\mathrm{Ag}$ & 3 & $10 \mathrm{E}-2-10 \mathrm{E} 0$ \\
$\mathrm{Ks}$ & 2 & $10 \mathrm{E}-6-10 \mathrm{E}-5$ \\
$\mathrm{Ksg}$ & 1 & $10 \mathrm{E}-3-10 \mathrm{E} \cdot 4$ \\
$\mathrm{Kg}$ & 11 & $10 \mathrm{E}-2-10 \mathrm{E} \cdot 4$ \\
\hline
\end{tabular}

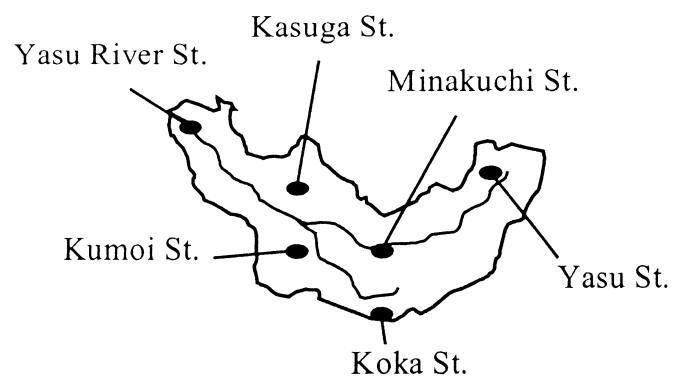

Fig. 8 Distributed weather and gauging stations at the $\mathrm{Y}$ asu River.

time series data of the observed groundwater levels and groundwater extraction amounts have not been sufficiently available for the whole basin. Limited investigations conducting the amounts of pumped water were carried out. Therefore the involved uncertainty is evaluated by the manual calibration of the model. Three-dimensional simulations for the unconfined groundwater levels were also carried out. A one-year simulation was done by using these data and by applying physical parameters obtained from field. These data was set as initial conditions for the groundwater flow model. There are many weather stations and rain gauges distributed allover the $\mathrm{Y}$ asu River basin. A mong these stations there are only six stations with a reliable time series data. The locations of these stations are shown in Fig. 7. These data includes 30 years of hourly meteorological data, hourly water intake, and hourly-observed river stage.

\section{SIMULATION RESULTS AND DISCUS- SION}

The proposed integrated Hydro-BEAM is applied to hourly data from the upper and lower catchments. Initial saturated depth profiles were evaluated according to the distributed groundwater levels. The undefined parameters were adjusted by trial and error in order to minimize the residual errors between the calculated and the observed data. Snow depth, and evapotranspiration are shown in Fig. 9. Precipitation and the corresponding runoff in the $\mathrm{Y}$ asu River basin outlet are 


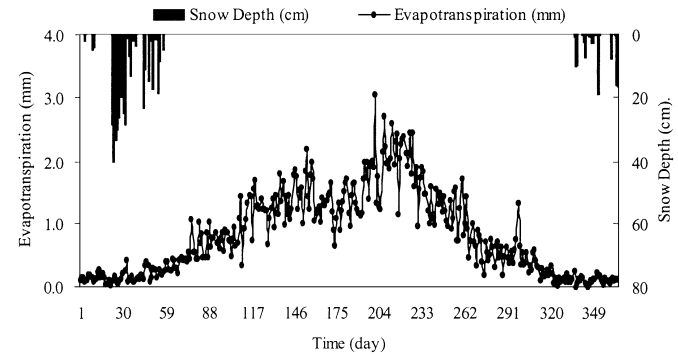

Fig. 9 Sim ulated evapotranspiration and snow depth in upper Y asu River Basin (1997).

show $n$ in Fig. 10. T here are three discharge observation stations at the $\mathrm{Y}$ asu River basin. $\mathrm{T}$ he correlation values between observed and calculated values vary within the basin. The fluctuations are caused by the calibration of the model. Since the hydrological parameters of the distributed land uses and soils are varying for each grid, the calibration of the discharge at one station will not necessarily lead to good agreements between the observed and simulated values at other observation stations.

$\mathrm{T}$ he river discharge measurements at the $\mathrm{Y}$ asu River are performed daily. The daily measurements do not show the propagation of the kinematic wave from the upper catchments due to averaging of hourly readings. The simulated and observed daily discharges at Minakuchi station are show $n$ in Fig. 11.

T he response of the river hydrograph due to upstream flow is not the same for upper and lower catchments, the runoff related wave transfers faster in lower catchments. Fig. 12, and Fig. 13.

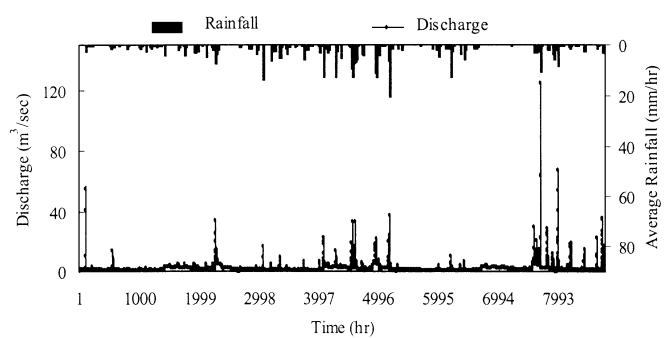

Fig. 10 Sim ulated river discharge and measured rainfall in lower Y asu River basin (1997).

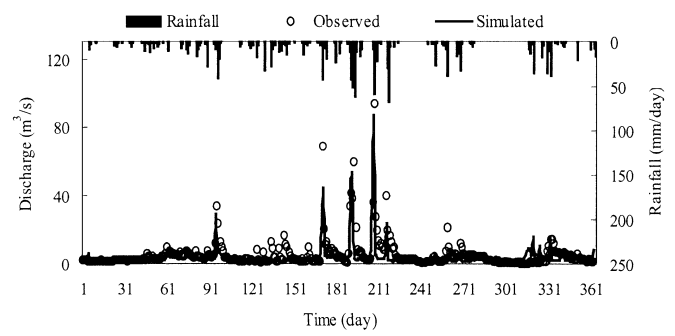

Fig. 11 Sim ulated and observed daily river discharges at Minakuchi station (1997).

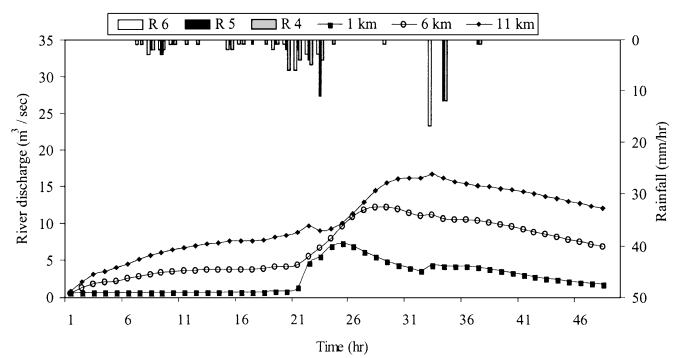

Fig. 12 T ime series of hourly river discharge in upper catchments.

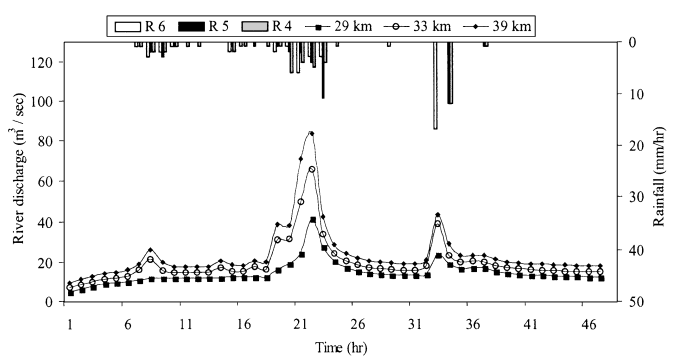

Fig. 13 T ime series of hourly river discharge in low er catchments.

show the plots of the flow hydrographs at various points along the river channel in the upper and low er catchments, respectively. It can be seen that the peak discharge is transferred as the runoff wave in the upper streams $(1 \mathrm{~km}, 29 \mathrm{~km})$. In these Figures the spatiotemporal distribution of the flow hydrograph can be seen for many points along the river channel. This change is caused by the difference in flow accumulation netw orks and the hydrological characteristics of the catchments. These char acteristics include rainfall, par ameters for infil- 


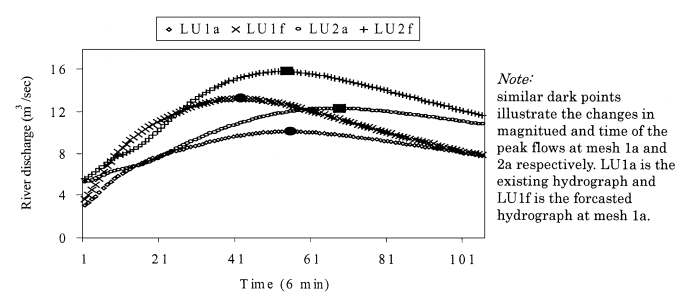

Fig. 14 T ime series of river discharges for land use change scenarios.

tration and roughness coefficients that are highly affected by both land uses and soil distribution.

The model is highly affected by the distribution of both land use and soil type in each grid. Many scenarios have been simulated for identifying the hydrological impacts of urbanization. Fig. 14 show $\mathrm{s}$ the impact of changing (30\%) of the agricultural areas into residential ar eas, and the related change in the river hydrographs in the upper $Y$ asu River ba$\sin$. In this figure, LU $1 f$ and LU $2 f$ represent the future shapes of the hydrographs LU1a, and LU 2a, respectively. Large points compose the for ecasted hy drographs.

The distributed soil moisture is highly affected by the existing sources and sinks within the unsaturated subsurface lay er. By considering the spatiotemporal parameterization, which is caused by the land use dynamics the soil moisture profile for each cell is simulated. A the start of the rain seasons the soil is assumed to be dry, and according to the soil ty pes and depths of groundw ater the potential head at the boundary of the unsaturated layer is evaluated. At the $\mathrm{Y}$ asu River basin the groundwater potential head value ranges from -40 to -100 $\mathrm{m}$, the soil layer is divided into (100) divisions between the surface and the groundwater level. Then the soil moisture and the distribution of the potential head is simulated at every $10 \mathrm{sec}$., during this small time step the groundwater level is assumed to be steady and is not affected by the soil moisture. A t every large time step the groundwater level is updated in order to set the lower boundaries for the unsaturated flow model. Since the initial potential head for dry conditions is smaller than any of the distributed hydraulic con-

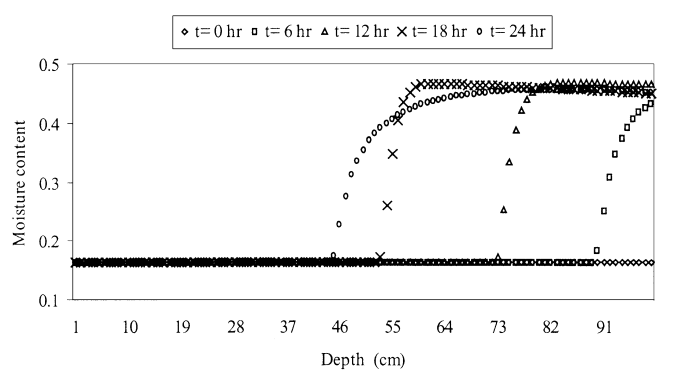

Fig. 15 Simulated spatiotemporal soil moisture contents in lower $\mathrm{Y}$ asu River basin.

ductivities, it is assumed that the soil will absorb a certain amount of the applied sources. This amount is highly affected by the existing utilization of land and seasonality. Then the calculated soil moistures will be accumulated for every large time step and used for estimating the distributed recharge to groundwater model. A Iso the model simulates the distributed discharges from groundwater storage, because the accumulated soil moisture can be negative in the case of dry weather conditions, and extensive water uptake from the subsurface layers. A demonstration for simulating the temporal soil moisture conditions is shown in Fig. 15.

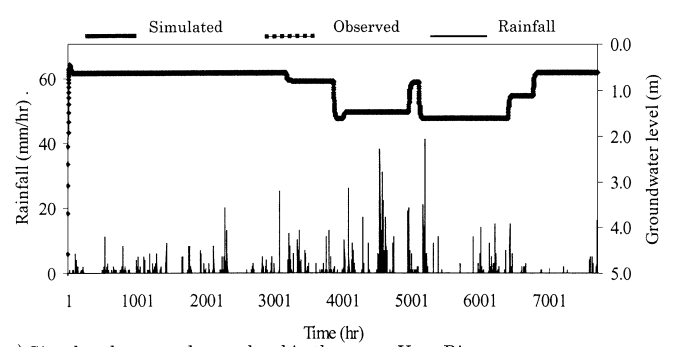

a) Simulated groundwater level in the upper Yasu River

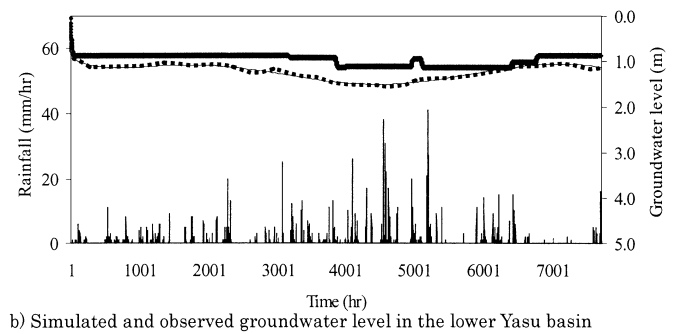

Fig. 16 Simulated groundwater level in the $\mathrm{Y}$ asu River basin. 

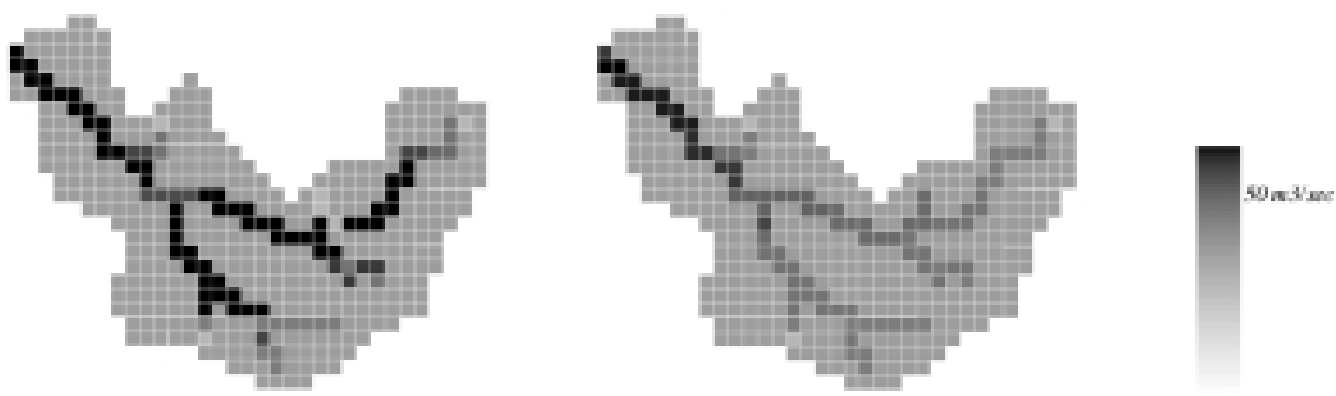

Fig. 17 Spatial distribution of river discharge at Y asu River (1997/11/1).

The groundwater level for each grid is simulated by the dynamic linking between the surface water models and groundwater model in the integrated Hydro-BEAM. The distributed groundwater levels for upper and lower catchments are shown in Fig. 16. Spatial distributions of river discharges and groundwater levels at $Y$ asu River basin are show $n$ respectively in Fig. 17, and Fig. 18.

$\mathrm{T}$ he operation of the $\mathrm{Y}$ asu dam is analyzed for a period of ten years. T he operation of the dam illustrates some of the unique problems, associated with a dam designed for flood protection and for storing of the runoff form the upper catchments. $T$ his ty pe of dams requires a seasonality-based operation rules, and in Hydro-BEA M the monthly operation is simulated according to the formulated operation method. The operation can be formulated as a polynomial of the order 6 as illustrated by Eq. (21). Table 3. illustrates the monthly formulation of the storage- release functions.

$$
\text { Release }=\sum_{i=1}^{6} a_{i} R S^{i}
$$

where $a_{i}$ is the poly nomial coefficients, $R S$ is the reservoir storage. Then the unsteady inflow hydrograph from the upper catchments is routed through the reservoir, the initial outflow and as well as the initial storage, must be known. Using continuity the storage for a time step is given by

$$
2 R S_{j}=I_{j-1}+I_{j}-R I_{j-1}-R l\left(R S_{j}\right)
$$

where $I$ is the inflow and $R l$ is the release. The $R S$ value can be used to calculate $R l$ for a time step by applying an iteration method.

$\mathrm{T}$ he operation of $\mathrm{Y}$ asu dam and $\mathrm{A}$ oto dam is formulated according to the explained methodology

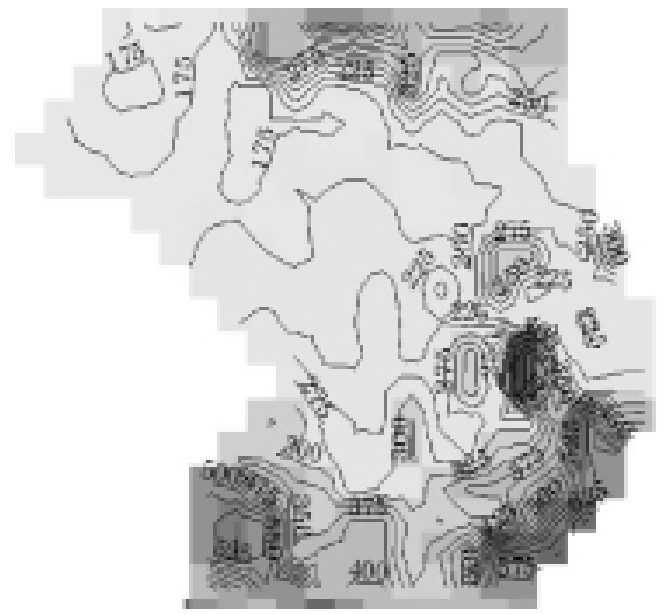

Fig. 18 Spatial distribution of groundwater level at $\mathrm{Y}$ asu River basin (1997/11/1, 11:00 A M ).

T able 3 Formulated monthly operation rules for

\begin{tabular}{|c|c|c|c|c|c|c|}
\hline Month & $a_{1}$ & $a_{2}$ & $a_{3}$ & $a_{4}$ & $a_{5}$ & $a_{6}$ \\
\hline 1 & 0 & 298.7 & $\cdot 32278$ & 12992 & $\cdot 23820$ & 10400 \\
\hline 2 & 0 & $2.00 \mathrm{E}-15$ & $-4.00 \mathrm{E}-11$ & $4.00 \mathrm{E}-07$ & -0.0017 & 2.689 \\
\hline 3 & $8.00 \mathrm{E} \cdot 18$ & $\cdot 3.00 \mathrm{E} \cdot 13$ & $4.00 \mathrm{E} \cdot 09$ & $\cdot 2.00 \mathrm{E} \cdot 05$ & $7.83 \mathrm{E}-02$ & $\cdot 1.03 \mathrm{E}+02$ \\
\hline 4 & 0 & $2.00 \mathrm{E}-15$ & $-6.00 \mathrm{E} \cdot 11$ & $6.00 \mathrm{E} \cdot 07$ & $\cdot 0.0025$ & 4.176 \\
\hline 5 & 0 & $2.00 \mathrm{E} \cdot 16$ & $\cdot 6.00 \mathrm{E} \cdot 12$ & $5.00 \mathrm{E} \cdot 08$ & $\cdot 0.0002$ & 0.3352 \\
\hline 6 & $3.00 \mathrm{E} \cdot 19$ & $\cdot 7.00 \mathrm{E} \cdot 15$ & $7.00 \mathrm{E} \cdot 11$ & $\cdot 4.00 \mathrm{E}-07$ & $9.00 \mathrm{E}-04$ & $\cdot 9.48 \mathrm{E}-01$ \\
\hline 7 & 0 & $0.00 \mathrm{E}+00$ & $2.00 \mathrm{E} \cdot 11$ & $\cdot 4.00 \mathrm{E} \cdot 07$ & 0.0029 & -6.289 \\
\hline 8 & $1.00 \mathrm{E}-20$ & $\cdot 3.00 \mathrm{E} \cdot 16$ & $2.00 \mathrm{E} \cdot 12$ & $-9.00 \mathrm{E}-09$ & $2.00 \mathrm{E}-05$ & $\cdot 1.28 \mathrm{E}-02$ \\
\hline 9 & $3.00 \mathrm{E} \cdot 19$ & $\cdot 6.00 \mathrm{E} \cdot 15$ & $4.00 \mathrm{E}-11$ & $-2.00 \mathrm{E}-07$ & $3.00 \mathrm{E}-04$ & $\cdot 1.81 \mathrm{E}-01$ \\
\hline 10 & $0.00 \mathrm{E}+00$ & $5.00 \mathrm{E} \cdot 15$ & $-5.00 \mathrm{E}-11$ & $2.00 \mathrm{E} \cdot 07$ & $\cdot 2.00 \mathrm{E} \cdot 04$ & $1.16 \mathrm{E}-01$ \\
\hline 11 & $1.00 \mathrm{E} \cdot 18$ & $\cdot 1.00 \mathrm{E} \cdot 13$ & $1.00 \mathrm{E} \cdot 09$ & $-6.00 \mathrm{E}-06$ & $1.10 \mathrm{E}-02$ & $\cdot 7.48 \mathrm{E}+00$ \\
\hline 12 & $4.00 \mathrm{E} \cdot 19$ & $\cdot 7.00 \mathrm{E}-15$ & $5.00 \mathrm{E}-11$ & $-2.00 \mathrm{E}-07$ & $4.00 \mathrm{E}-04$ & $-2.75 \mathrm{E}-01$ \\
\hline
\end{tabular}
the $\mathrm{Y}$ asu dam.

in the previous section. T he monthly formulated operation is applied to $\mathrm{Y}$ asu dam, then the calculated release is added to the simulated runoff in order to 


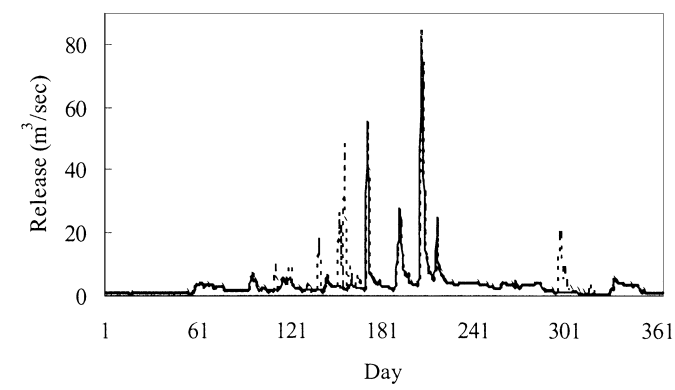

Fig. 19 Modified dam release at A oto Dam (dashed line), 1997.

estimate the inflow at $A$ oto dam. T he operation at A oto dam is evaluated according to the river discharge at $\mathrm{Y}$ asu River station, which is located 15 $\mathrm{km}$ far away. Fig. 19 shows the actual release at A oto dam and the periods where the operation of A oto dam has failed to satisfy the monitoring value ( $\left.1.68 \mathrm{~m}^{3} / \mathrm{sec}\right)$. Therefore Hydro-BEA M is used to identify these faults in dam operation and optimizes the release by using the iterative operation method.

\section{CONCLUSION}

A general framework for the integrated hydrological modeling has been presented. The framework includes three main linked models; distributed rainfall-runoff model, unsaturated flow model, and unconfined groundw ater model. T he importance of linking the three models has been illustrated and emphasized. Manual calibration has been conducted for the case study of the $\mathrm{Y}$ asu River basin. T he simulated groundw ater levels and the river discharges show a good agreement with the observed values, but in certain catchments there was a poor agreement with the corresponding observed data.

The manual calibration procedure for the model parameters doesn't succeed in finding global optimal values because the spat-iotemporal fluctuations of the basin characteristics might harden the attempts for finding global optimal parameters for every catchment within the basin. The integrated hydrological modeling including groundwater and surface water might require long time periods for automatic calibration and more research is needed in this subject.

ACKNOWLEDGEMENTS: The authors, herein, would like to express our heartfelt gratitude to Dr. T achikawa, Disaster Prevention Institute, Kyoto University for his kind assistance and we are grateful to the members of the Suido Work Office in Shiga Prefecture for their friendliness to provide the necessary data and information, and to the reviewers for reviewing the manuscript and providing helpful comments to improve the paper.

\section{REFERENCES}

Baker D.L., (1995b) : Darcian weighted inter-block conductivity means for vertical unsaturated flow, Groundwater, V ol. 33, No. 3, pp. 385-390.

Beldring S., (2000) : Kinematic wave approximations to hillslope hydrological processes in tills, Hydrological Process, V ol. 14, No. 1, pp. 727-745.

Beven K., (1982) : On subsurface storm flow: an analysis or response times, Hydrological Science Journal, V ol. 4, No. 1, pp. 505-521.

Bouwer H., (1978) : Water resources and environmental engineering, $1^{\text {st }}$ edition, M Graw- Hill.

Chow V., (1988) : Applied hydrology, $1^{\text {st }}$ edition, McGraw-Hill.

Horton R. E., (1919) : Rainfall Interception, Monthly Weather Review, V ol. 47, No. 1, pp. 603-623.

Ishihara T., (1959) : Fundamental researches on the unit hydrograph method and its application, Japan Society of Civil Engineers, V ol. 60, No. 3-3, pp. 19.

Jennifer P., Mark P., W illiam j., Gutow ski, T homas C., (2002) : Putting aquifers into atmospheric simulation models: an example from the Mill Creek Watershed, northeastern Kansas, $A d$ vances in Water Resources, V ol. 25, No. 1, pp. 221238.

Johansson P., (1986) : Diurnal groundwater level fluctuations in sandy till-a model analy sis, Journal of Hydrology, V ol. 87, No. 1, pp. 125-134.

Kato T., (2002) : Research on the water cycle for the upper basin of the Yasu River, $1^{\text {st }}$ edition, Ky oto 
University.

Kimaro T ., (2002) : Groundw ater modeling coupled with SVAT model and its application to the Y asu River basin, Annual DPRI, Kyoto University, Vol. 45, No. 1, pp. 163-170.

Kojiri T., (2000) : GIS-based environment model for water quantity and quality with river basin simulation, Annual DPRI, Kyoto University, V ol. 44, No. 1, pp. 150-160.

Park J., Kojiri T., T omosugi K., (2003) : Develop- ment of GIS based distributed runoff model for environmental assessment, Japan Soc. Hydrol. \& Water Resources, V ol. 16, No. 1, pp. 541-555.

Richards L. A ., (1931) : Capillary conduction of liquids through porous media. Physics 1, pp. 318-333. Shin H., (1979) : Modeling of rivers. $1^{\text {st }}$ edition, W iley. W ang H., A nderson M., (1982) : Introduction to groundwater modeling, A cademic Press.

(Received : Mar. 10, 2004, A ccepted : Oct. 30, 2004) 